http://dx.doi.org/10.12775/szhf.2021.003

\author{
Marek Soltysiak \\ Uniwersytet Papieski Jana PawŁa II w Krakowie \\ E-MAIL: MAREK.SOLTYSIAK@UPJP2.EDU.PL \\ ORCID: 0000-0003-4437-0321
}

\title{
Problematyczność przedmowy Ad Lectorem Andrzeja Osiandra do De revolutionibus Mikołaja Kopernika
}

Żadna inna przedmowa do książki nie spotkała się z taką krytyką, jaka dotknęła Ad Lectorem de hypothesibus hujus operis (Do czytelnika o zasadach tego dzieła) do De revolutionibus Mikołaja Kopernika. Stała się ona, od chwili wydania opus vitae Kopernika w Norymberdze w 1543 roku, przedmiotem licznych nieporozumień. Ze względu na swoją zawartość jest niezgodna z treścią prezentowaną w samym dziele ${ }^{1}$. Rodzi się zatem pytanie: dlaczego w ogóle została w nim umieszczona? Trudno wyjaśnić także jej anonimowość. Dlatego na początku artykułu spróbuję przywołać i uporządkować podstawowe zarzuty, z jakimi spotkała się ona od samego początku, tj. od 1543 roku, aż do czasów nam współczesnych. W celu usystematyzowania dostępnych wiadomości mających wpływ na powstanie pracy w dalszej jej części podejmę się

1 Niezgodność pomiędzy treścią Przedmowy a treścią De revolutionibus zauważyli natychmiast przyjaciele Kopernika. W egzemplarzach wydania norymberskiego dokonali oni skreśleń dodatków redakcyjnych, które nie pochodziły od samego Kopernika. 
rekonstrukcji wydarzeń poprzedzających wydanie dzieła. W tym przypadku natrafiamy na duże trudności, ponieważ korespondencja związana bezpośrednio z wydaniem De revolutionibus jest zdekompletowana ${ }^{2}$. Pomimo niedostatku materiałów źródłowych podejmę próbę odpowiedzi na pytanie, jakimi motywami kierował się Andrzej Osiander (1498-1552) w jej napisaniu i dlaczego pozostawił ją niepodpisaną. W kolejnej części artykułu, spróbuję wyjaśnić nieporozumienie związane z usunięciem przez Osiandra Praefatio (Przedmowy) Kopernika do De revolutionibus i uzasadnić, czym kierował się, dokonując innych zmian redakcyjnych.

Jednym $\mathrm{z}$ najważniejszych zagadnień filozoficznych $\mathrm{w}$ historii nauki był status teorii naukowych. W związku z nim publikacja dzieła De revolutionibus w 1543 roku wzbudziła kontrowersje zarówno ze względu na pogląd Kopernika dotyczący ruchu Ziemi, jak i z powodu rozbieżności pomiędzy jego nowatorskim twierdzeniem o prawdziwości teorii heliocentrycznej a dominującym wówczas poglądem o hipotetycznej naturze każdej teorii astronomicznej. ${ }^{3}$ Można powiedzieć, że źródłem nieporozumień związanych z Ad Lectorem jest niezrozumienie przez Osiandra tej różnicy. Przyjął on hipotezę „ratowania zjawisk” 4 jako podstawę nakłaniania czytelników do dokładnego rozważenia szokujących pomysłów Kopernika. Ostatnia część artykułu będzie poświęcona temu zagadnieniu.

\footnotetext{
2 Por. Jerzy Drewnowski, Mikołaj Kopernik w świetle swej korespondencji (Wrocław-Warszawa-Kraków-Gdańsk: Ossolineum, 1978).

3 Por. Thomas S. Kuhn, Przewrót kopernikański, przeł. Stefan Amsterdamski (Warszawa: Prószyński i S-ka SA., 2006), 218.

${ }^{4}$ Hipotezy astronomiczne zarówno w starożytności, jak i w średniowieczu wymyślone przez astronomów nie rościły sobie (w przeważającej większości) pretensji do ukazania prawdy o ruchach ciał niebieskich. Były one matematycznymi fikcjami i pełniły „[...] rolę instrumentu służącego do ekonomicznego rekonstruowania zaobserwowanych zjawisk niebieskich i do przewidywania ich przyszłego przebiegu" (Michał Kokowski, Różne oblicza Mikołaja Kopernika. Spotkania $z$ historia interpretacji (Warszawa-Kraków: Instytut Historii Nauki

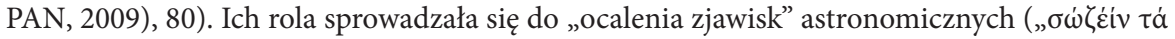

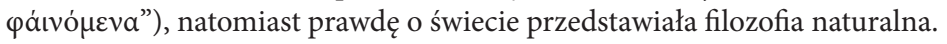




\section{Reakcja na Ad Lectorem}

Wiosną 1543 roku wydrukowane kopie De revolutionibus otrzymał Retyk (Jerzy Joachim von Lauchen 1514-1574). Zirytował go fakt, iż do dzieła dodano anonimową przedmowę Ad Lectorem na temat natury hipotez. Na dwóch egzemplarzach - jednym znajdującym się w prywatnej kolekcji Harrisona Horblita w Connecticut i drugim zachowanym w Bibliotece Uniwersyteckiej w Uppsali - przekreślił ją czerwonym ołówkiem ${ }^{5}$. Zaczął podejrzewać, że jej autorem jest Osiander ${ }^{6}$. Wysłał dwa egzemplarze De revolutionibus dla biskupa chełmińskiego Tiedemanna Giesego (1480-1550) z listem (zaginionym), w którym potępił „przewrotność” drukarza norymberskiego Johannesa Petreiusa (1497-1550), za umieszczenie w nim bez zgody i wie-

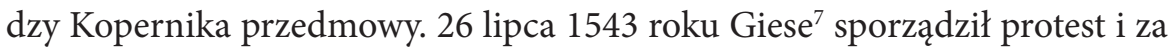
pośrednictwem Retyka skierował go do Rady Miejskiej w Norymberdze, a ta przekazała go Petreiusowi, żądając przywrócenia wierności dziełu. Jego odpowiedź (która, podobnie jak protest, nie przetrwała do naszych czasów) została oceniona przez Radę Miasta 29 sierpnia 1543 roku za zbyt ostrą. Po jej złagodzeniu wysłano ją Giesemu wraz z decyzją Rady, że nie ma żadnych podstaw, aby podjąć działania przeciwko Petreiusowi ${ }^{8}$.

5 Por. Owen Gingerich, „From Copernicus to Kepler: Heliocentrism as Model and as Reality". Proceedings of the American Philosophical Society 117, 6 (1973): 514.

6 Por. Edward Rosen, Three Copernican Treatises. The Commentariolus of Copernicus. The Letter against Werner. The Narratio prima of Rheticus (New York: Octagon Books, 1971), 404-405.

7 Por. Marian Biskup, „Regesta Copernicana”, Studia Copernicana, VII, 503 (Wrocław-Warszawa-Kraków-Gdańsk: Ossolineum, 1973): 219-220; por. Jerzy Sikorski, „Mikołaj Kopernik na Warmii, chronologia życia i działalności”, w: Kopernik na Warmii. Życie i działalność publiczna. Działalność naukowa. Środowisko. Kalendarium 567, red. Janusz Jasiński, Bohdan Koziełko-Poklewski, Jerzy Sikorski (Olsztyn: Stacja Naukowa Polskiego Towarzystwa Historycznego (Instytut Mazurski), Ośrodek Badań Naukowych im. Wojciecha Kętrzyńskiego, 1973), s. 518-519. Giese chciał przygotować poprawioną edycję De revolutionibus. Nie doszło to jednak do skutku.

8 Por. Biskup, „Regesta Copernicana” 503: 219-229; Sikorski, „Mikołaj Kopernik na Warmii, chronologia życia i działalności” 570: 519. Oryginał zaginął. Por. Ignacy Polkowski, Kopernikijana, czyli materiały do pism i życia Mikołaja Kopernika, t. 1 (Gniezno: Drukiem J. B. Langiego, 1873), 91-93. 
Według Ludwika Antoniego Birkenmajera oprócz Giesego także Jan Brożek (łac. Joannes Brocius 1585-1652) zareagował na dodany, anonimowy wstęp, ponieważ wypaczał on intencje Kopernika. W związku z tym dokonał skreśleń dodatków redaktorów na swoim egzemplarzu De revolutionibus, których nie było w autografie 9 . Jego protest, podobnie jak reakcja Retyka, miał jednak charakter prywatny.

Dopiero kilkadziesiąt lat później Joachim Kepler (1571-1630) w Apologia Tychonis (Brahe) contra Ursum (Raimorum Dithmarsium), napisanej w 1601 roku, ujawnił, że to Osiander jest jej autorem ${ }^{10}$. Apologia powstała w 1601 roku, ale „[...] wskutek śmierci Dithmarsa i Brahego stała się bezcelową i jako rękopis utonęła w papierach Keplera”. Została opublikowana dopiero w 1858 roku $^{11}$. Prawdę o autorstwie Ad Lectorem ujawnił Kepler osiem lat później, w Astronomii nowej wydanej w 1609 roku $^{12}$.

Roman Ingarden, biorąc po uwagę opracowania dotyczące głównego dzieła Kopernika ${ }^{13}$, szczególnie polskie, stwierdził, że „[...] postać Osjandra i jego przedmowa do De revolutionibus otaczane są lekceważeniem i pogardą" ${ }^{14}$. W 1854 roku Julian Bartoszewicz, w Przedmowie ttumacza do warszawskiego wydania $O$ obrotach ciał niebieskich z 1854 roku, zarzuca Osiandrowi, że usunął Przedmowę Kopernika, a umieścił własną na jej miejscu ${ }^{15}$. Pięćdzie-

9 Por. Ludwik A. Birkenmajer, Mikołaj Kopernik. Część pierwsza. Studya nad pracami Kopernika oraz materyały biograficzne (Kraków: Akademya Umiejętności, 1900), 656; por. Sikorski, „Mikołaj Kopernik na Warmii, chronologia życia i działalności” 567: 518.

10 Por. Johannes Kepler, „Apologia pro Tychone contra Ursum”, w: The Birth of History and Philosophy of Science: Kepler's „A Defence of Tycho against Ursus” with essays on its provenance and significance, red. Nicholas Jardine (Cambridge: Cambridge University Press. Reprint, 1988), 150; por. Birkenmajer, Mikołaj Kopernik, 649.

11 Por. Birkenmajer, Mikołaj Kopernik, 650.

12 Późniejsze wydania De revolutionibus (Bazylea 1566 i Amsterdam 1617) wydrukowały Przedmowę Osiandra bez komentarza, pozostawiając czytelnika w przekonaniu, że jej autorem jest Kopernik. Dopiero wydanie warszawskie z 1854 roku wspominało o autorstwie Osiandra.

${ }^{13}$ Michał Kokowski w swojej monografii zebrał bogatą literaturę dotyczącą różnych, często sprzecznych, interpretacji myśli Kopernika, jak również roli Osiandra w publikacji De revolutionibus. Por. Kokowski, Różne oblicza Mikołaja Kopernika.

14 Roman S. Ingarden, Fizyka i fizycy. Studia i szkice z historii i filozofii fizyki (Toruń: Wydawnictwo Uniwersytetu Mikołaja Kopernika, 1994), 50.

15 Por. Julian Bartoszewicz, „Przedmowa tłumacza”, w: Mikołaja Kopernika Toruńczyka, O obrotach ciał niebieskich. Ksiąg sześć, przeł. Jan Baranowski (Warszawa: Drukarnia Stanisława Strąbskiego, 1854), LXXIII-LXXIV. 
siąt lat później Ludwik Antoni Birkenmajer, biorąc pod uwagę opinię badaczy niemieckich, zwrócił uwagę na negatywne cechy osobowości Osiandra jako główne przyczyny jego „szalbierstwa"16. "Jakim był Andrzej Osiander, można się dowiedzieć z Doppelmayra, Willa i innych: »Er war grob, bissig, hochmüthig, eigensinnig, zänkisch, neidisch, unordentlich im Essen und Trinken«, mówi nam Will (III. Pag. 91), a to, co umie o nim powiedzieć wyrozumiały na ułomności ludzkie Filip Melanchton, przychodzi czytać ze wstrętem. Kto by się interesował tą posępną postacią na tle ówczesnego ruchu reformacyjnego..." ${ }^{17}$. Oceniając jego zaangażowanie przy norymberskiej redakcji De revolutionibus, wyraża się o nim wręcz pogardliwie ${ }^{18}$. Na poparcie swojej awersji do niego przytacza słowa Giesego z listu do Retyka z 26 lipca 1543 roku o „norymberskich machinacyach” związanych z „perfidią wydawców”19. W końcu, wskazując na „krzywdę”, jaką Osiander wyrządził dziełu Kopernika, nazywa go „synem ciemności”"20. Alojzy Tujakowski, pół wieku po Birkenmajerze, uznaje zarówno norymberskich wydawców, jak i samego Osiandra za „fałszerzy”21.

Bardziej wyważony sąd wobec czynu Osiandra prezentują Jaremi Wasiutyński i Roman Stanisław Ingarden. Wasiutyński, analizując listy Osiandra do Kopernika, zwraca uwagę na jego poglądy dotyczące hipotez naukowych, które różniły się zasadniczo od poglądów Kopernika i jako takie były przyczyną nieporozumień2 ${ }^{2}$. Podobnie Ingarden kładzie nacisk na jego cechy charakteru, które doprowadziły go do niezrozumienia intencji Kopernika. „Impulsywny i ambitny, nie mogąc wymusić na Koperniku przedmowy według własnej koncepcji, decyduje się na nielojalny wobec niego krok: usuwa oryginalną przedmowę

16 Por. Birkenmajer, Mikołaj Kopernik, 650.

17 Tamże, 404.

18 Por. Ludwik A. Birkenmajer, „Przedmowa”, w: Mikołaj Kopernik, Wybór pism w przekładzie polskim, przeł. Ludwik A. Birkenmajer (Kraków: Druk w I. Anczyca i Spółki, 1920), 23.

19 Por. Birkenmajer, Mikołaj Kopernik, 402.

20 Por. Birkenmajer, „Przedmowa”, 24.

${ }^{21}$ Por. Alojzy Tujakowski, Mikołaja Kopernika „De revolutionibus”. Historia wydań (Toruń: PWN 1973), 28.

${ }^{22}$ Por. Jeremi Wasiutyński, Kopernik, twórca nowego nieba (Warszawa: J. Przeworski, 1938), 462. 
Kopernika umieszczoną przed pierwotnym tekstem [...] i daje na jej miejsce własną, nie podpisaną"23.

Bruce Wrightsman ${ }^{24} \mathrm{w}$ artykule Andreas Osiander's Contribution to the Copernican Achievement analizuje przyczyny i skutki umieszczenia Ad Lectorem w dziele. Skupia się na samej treści, nie bierze natomiast pod uwagę wymiany listów pomiędzy Kopernikiem i Osiandrem ${ }^{25}$. Ważny aspekt myśli Osiandra wskazuje także Alain Boyer ${ }^{26} \mathrm{w}$ artykule The Osianderian compromise. Jego zdaniem Ad Lectorem jest de facto jednym z pierwszych tekstów dotyczących tzw. instrumentalistycznej teorii nauki. Z jednej strony jest ona krytykowana przez realistów XX wieku (Alexandra Koyre’a i Karla Poppera), a z drugiej broniona jest przez instrumentalistów, m.in. przez Pierre’a Duhema (1861-1916), w jego słynnej książce Sôzein ta phainomena ${ }^{27}$.

W literaturze przedmiotu dotyczącej Osiandra autorzy są zgodni, jeśli idzie o jego nieprzejednany charakter, który był nie tylko powodem jego kłopotów osobistych, ale miał wpływ na niezrozumienie nowej koncepcji metody przedstawionej i zastosowanej w De revolutionibus. Autorzy, którzy porównują treść Ad Lectorem z treścią De revolutionibus, uznają Osiandra za wroga heliocentryzmu i nauki. Główny zarzut, jaki mu stawiają, dotyczy „oszukania” czytelnika, że przedstawione w niej poglądy są stanowiskiem Kopernika. Innymi słowy, że hipoteza heliocentryczna jest pomocnym modelem matematycznym w tłumaczeniu zjawisk, a nie rzeczywistym obrazem świata. Natomiast komentatorzy, którzy zwracają uwagę tylko na treść samej przedmowy Osiandra, widzą w nim prekursora instrumentalizmu w filozo$\mathrm{fii}^{28}$.

23 Ingarden, Fizyka i fizycy, 39.

24 Por. Bruce Wrightsman, „Andreas Osiander's Contribution to the Copernican Achievement”, w: The Copernican Achievement, red. Robert S. Westman (Berkeley-Los Angeles-London: University of California Press, 1975).

${ }^{25}$ Chociaż listy te zaginęły, to dzięki Keplerowi znamy ich treść pośrednio. Por. Drewnowski, Mikołaj Kopernik w świetle swej korespondencji, 72-78.

26 Por. Alain Boyer, "The Osianderian compromise”, w: The Problem of Rationality in Science and its Philosophy: on Poper vs. Polanyi, the Polish Conference 1988-89, red. Józef Misiek (Boston Studies in the Philosophy of Science, vol. 160, Dordrecht: Springer, 1995), 55-63.

27 Por. Pierre Duhem, Sôzein ta phainomena. Sozein ta phainomena. Essai sur la Notion de Théorie physique de Platon à Galilée (Paris: A. Hermann et Fils, 1908).

28 Instrumentalizm jest odmianą pragmatyzmu (John Dewey). Dla instrumentalizmu hipotezy służą jedynie jako środki dla zaspokojenia potrzeb praktycznych. „Prawdę jako 
Aby w miarę obiektywnie, ze względu na odczuwalny brak źródeł historycznych, ocenić umieszczenie Ad Lectorem na początku dzieła, spróbujmy prześledzić tok wydarzeń związanych z wydaniem De revolutionibus.

\section{Chronologia wydarzeń związanych z publikacją De revolutionibus}

W 1538 roku Retyk podczas swej podróży naukowej po Europie Środkowej na krótko zatrzymał się w Norymberdze i zamieszkał w domu Johannesa Schönera (1477-1547), znanego nauczyciela matematyki i astronomii, z którym dyskutował na temat astronomii Kopernika. W Norymberdze spotkał się także z drukarzem Johannesem Petreiusem i z Osiandrem. W drugiej połowie maja 1539 roku dotarł do Fromborka i nawiązał kontakt z Kopernikiem. Podarował mu pięć dzieł składających się na trzy tomy ${ }^{29}$. Szczególnie trzy dzieła opublikowane w Norymberdze miały istotne znaczenie dla wydania drukiem De revolutionibus. Były one świadectwem profesjonalności, z jaką

przedmiot kontemplacji uważają za cel nieinteresujący lub utopijny. Niekiedy odrzucają samo pojęcie prawdy jako niezrozumiałe albo redukują prawdę do wartości instrumentalnych, najczęściej do trafności przewidywań wyprowadzonych za pomocą teorii” (Adam Grobler, Metodologia nauk (Kraków: Wydawnictwo Aureus-Wydawnictwo Znak, 2006), 257). Określona teoria jest narzędziem pragmatycznym, a nie rzeczywistym opisem realnego świata. Przy wyborze danej hipotezy decydującym argumentem jest jej prostota i użyteczność, a nie jej prawdziwość. Por. Wojciech Sady, „Przeciwko instrumentalizmowi”, Studia Filozoficzne 10 (1983): 145-152. Por. Karl R. Popper, „Three views concerning human knowledge”, w: Karl R. Popper, Conjectures and refutations: The growth of scientific knowledge (London: Routledge, 1965), 97-119.

${ }_{29}$ Por. Jarosław Włodarczyk, „Wstęp”, w: Jerzy J. Retyk, Relacja pierwsza z ksiag „O obrotach” Mikołaja Kopernika, przeł. Ignacy Lewandowski (Warszawa: Wydawnictwo Uniwersytetu Warszawskiego, 2015), 31-32. Tom pierwszy zawierał Almagest Ptolemeusza, wydany w Bazylei (1538); na tom drugi składały się dwie prace opublikowane w Norymberdze w oficynie Petreiusa: Optika Witelona (1535) oraz Petro Apiano, Instrumentum primi mobilis (z dołączonym traktatem Gebera De astronomia, 1534); trzeci tom obejmował także dwie prace: greckie teksty Elementów Euklidesa, wydane w Bazylei (1533) oraz De triangulis omnimodis Johanna Müllera Königsberga zwanego Regiomontanusem, wydane w Norymberdze (1533) przez Petreiusa. Por. Włodarczyk, „Wstęp”, 64. 
oficyna Petreiusa edytuje prace uczonych, i niejako zapowiedzią, że dzieło astronoma $\mathrm{z}$ Fromborka równie starannie zostanie wydane.

Retyk po zaznajomieniu się $\mathrm{z}$ rękopisem (autografem) De revolutionibus sporządził jego streszczenie w niewielkiej książce zatytułowanej De libris revolutionum Copernici narratio prima (Relacja pierwsza z ksiag „O obrotach” Mikołaja Kopernika), zwanej Narratio prima (Relacja pierwsza). Książka powstała $\mathrm{w}$ ciągu kilkunastu tygodni ${ }^{30}$, tworzona była od końca maja do 23 września 1539 roku $^{31}$. Zostały w niej przedstawione argumenty za słusznością heliocentrycznego modelu świata. Swój dyskurs Retyk podsumował następująco: „Wszystkie te zjawiska w sposób widoczny są niby złotym łańcuchem przepięknie ze sobą powiązane. Każda planeta swoim położeniem, swym układem i wszelką zmianą swojego ruchu poświadcza ruch Ziemi”32. Narratio prima została wydrukowana na początku 1540 roku w gdańskiej oficynie Franciszka Rodego ${ }^{33}$. Kilka egzemplarzy ${ }^{34}$ zostało przekazanych przez Andrzeja Aurifabera (1514-1559) Osiandrowi. Był on pod dużym wrażeniem doktryny Kopernika przedstawionej w Relacji pierwszej. Po jej lekturze, w liście ${ }^{35} \mathrm{z} 1$ lipca 1540 roku, zwrócił się z usilną prośbą do Retyka: „Proszę Cię z całych sił, abyś, tak jak zaoferowałeś mi swoją przyjaźń, nie zaniechał wysiłków, by uczynić z tego męża [Kopernika] również mojego przyjaciela”36.

W sierpniu tego samego roku Petreius w przedmowie do traktatu astrologicznego Antoniego de Montulmo De judiciis nativitatum umieszcza list dedykacyjny dla autora Narratio prima. Wychwala w nim jego mądrość i pracę dla dobra nauki. W końcu ujawnia swój zamiar: ma nadzieję na pośrednictwo Retyka w wydaniu dzieła Kopernika w jego drukarni ${ }^{37}$.

30 Por. Jerzy J. Retyk, Relacja pierwsza z ksiag „O obrotach” Mikołaja Kopernika, przeł. Ignacy Lewandowski (Warszawa: Wydawnictwo Uniwersytetu Warszawskiego, 2015), 72.

31 Por. tamże, 147.

32 Tamże, 117-118.

33 Por. Birkenmajer, „Przedmowa”, 22.

34 Por. Martha List, „Marginalien zur Handexemplar Keplers von Copernicus: De revolutionibus orbium coelestum (Nümberg, 1543)", Studia Copernicana 16 (1978): 456.

35 Osiander odpowiada na niezachowany list Retyka. Por. Włodarczyk, „Wstęp”, 23.

36 „Sed de his iam satis, quod super est, etiam atque etiam te rogo quemadmodum tuam mihi offers amicitiam, ita diligentiam adhibeas vt eius viri amicitiam quoque mihi concilies” (List, „Marginalien”, 456). Tłumaczył Jarosław Włodarczyk, „Wstęp”, 23.

37 Por. Biskup, „Regesta Copernicana” 442, 196; por. Sikorski, „Mikołaj Kopernik na Warmii, chronologia życia i działalności” 500, 506. 
Według relacji Keplera Kopernik napisał list do Osiandra 1 lipca $1540 \mathrm{roku}^{38}$. List ten zaginął i nie znamy jego treści. Był to okres przygotowań do wydania De revolutionibus i z pewnością dotyczył spraw z nim związanych. Kepler nie wspomina o jego treści, jednak z odpowiedzi Osiandra możemy ją zrekonstruować. Bez wątpienia zawierał on obawy Kopernika dotyczące publikacji dzieła, związane $\mathrm{z}$ przedstawioną $\mathrm{w}$ nim teorią heliocentryczną. Prosił w nim Osiandra o radę, w jaki sposób uniknąć ataków przeciwników ${ }^{39}$.

Osiander $^{40}$ odpowiedział Kopernikowi na jego list dopiero 20 kwietnia 1541 roku. Sprawa poruszona w nim jest na tyle ważna, iż w tym samym dniu napisał list do Retyka ${ }^{41}$. W obu listach proponuje, aby nowa astronomia (system heliocentryczny) była prezentowana nie jako fizycznie prawdziwa, ale jako użyteczne narzędzie do obliczania ruchów ciał niebieskich. Kepler w Apologia Tychonis contra Ursum przytacza kilka zdań z tego listu ${ }^{42}$. Fragment ten ma dla nas istotne znaczenie, ponieważ ukazuje sposób rozumienia hipotezy naukowej przez Osiandra. Według niego hipotezy nie są „,artykułami wiary”, lecz narzędziami służącymi do obliczeń położeń planet i gwiazd. Choćby były fałszywe, nie ma to większego znaczenia dla przeprowadzonych obliczeń, byleby tylko należycie przedstawiały zjawiskową stronę ruchu. Dla uwiarygodnienia swego stanowiska powołuje się na autorytet Ptolemeusza ojca geocentrycznej koncepcji świata. Według autora Almagestu można wytłumaczyć nierówności ruchu Słońca, biorąc pod uwagę w obliczeniach zarówno epicykl, jak i mimośród. Mimo iż rozwiązania te nie są ze sobą spójne, to przy obliczeniach można brać pod uwagę zarówno jedną, jak i drugą możliwość.

38 Por. Kepler, „Apologia pro Tychone”, 97. Kepler wspomina o nim: „Nam cum Copernicus anno 1540 Cal. Jul.: ad Osiandrum scripsisset; sic illi inter caetera responder Anno 1541. 20 Apr.” (Kepler, „Apologia pro Tychone”, 97).

39 Por. Biskup, „Regesta Copernicana” 453, 200.

40 List od Kopernika otrzymał dopiero w marcu 1541 roku. Por. List, „Marginalien”, 453.

${ }^{41}$ Por. Biskup, „Regesta Copernicana” 454, 201; por. Sikorski, „Mikołaj Kopernik na Warmii, chronologia życia i działalności"512, 509.

42 Por. Kepler, „Apologia pro Tychone”, 97 „De hypothesibus ego sic sensj semper, non esse aeticulos fidej, sed fundamenta calculj, ita ut, etiamsj falsae sint, modo motuum фaıvó $\mu \varepsilon v a$ exacte exhibeant, nihil referat; quis enim nos certiores reddet, an solis inaequalis motus ratione Epicyclj, an ratione Eccentriciatis con // tingat. Si Ptoemaej hypothses sequamur, cum id possit utrumque. Quare plausibile fore videretur, si hac de re in praefatione nonnihil attingeres. Sic enim placidiores redderes peripatheticos et Theologos, quos contradicturos metuis" (tamże, pisownia oryginalna). 
W podobny sposób, według Osiandra, należy postąpić w przypadku De revolutionibus. Kopernik powinien we wprowadzeniu do swego dzieła „napomknąć, że użył hipotezy heliocentrycznej jako użytecznego narzędzia do obliczeń astronomicznych. W ten sposób uspokoiłby zarówno perypatetyków, jak i teologów, których sprzeciwu się obawia.

W tym samym dniu, tj. 20 kwietnia 1540 roku, Osiander wysłał list do Retyka, w którym podobnie jak w liście do Kopernika przedstawił instrumentalne rozumienie hipotezy naukowej odnoszącej się do heliocentrycznej koncepcji świata ${ }^{43}$. W udostępnionym nam przez Keplera ${ }^{44}$ fragmencie listu znajduje się odpowiedź na pytanie, jak należy pojmować hipotezę w astronomii według ówczesnych standardów naukowych. Według teologów i arystotelików hipoteza jest dogodnym narzędziem używanym do wytłumaczenia ruchów gwiazd i planet. Jej zadaniem jest „ratowanie zjawisk”, a nie ukazywanie prawdy o nich ${ }^{45}$. Dlatego astronomowie do wyjaśnienia jednych i tych samych pozornych ruchów ciał niebieskich posługują się dogodnymi, przyjętymi przez siebie założeniami. Podstawowym kryterium użycia danej hipotezy nie jest jej prawdziwość, lecz skuteczność w przeprowadzeniu obliczeń. Osiander zwraca uwagę na ich tymczasowość. Według niego w przyszłości może pojawić się naukowiec, który stworzy dogodniejszą hipotezę, lepiej tłumaczącą to samo zjawisko. W związku z powyższymi argumentami proponuje, aby Kopernik w przedmowie do De revolutionibus przedstawił treść swego dzieła jako hipotezę ratującą zjawisko.

Osiander na powyższe propozycje zawarte w jego dwóch listach z 20 kwietnia 1540 roku otrzymał odpowiedź z Fromborka. Możemy się domyślać, że była ona wspólnie przedyskutowana i zredagowana przez mistrza i ucznia. $\mathrm{Na}$ jej ślad natrafiamy w Apologii. Zawiera ona niestety tylko jedno zdanie

43 Por. Sikorski, „Mikołaj Kopernik na Warmii, chronologia życia i działalności” 513, 509.

44 Por. Kepler, „Apologia pro Tychone”, 98. „Peripathetici et Theologj facile placabuntur, si audierint, ejusdem apparen motus varias esse posse hypotheses, nec eas afferj, quod certo ita sint, sed quod calculum apparentis et compositj motus quam commodissime gubernet. Et fieri posse ut alius quis alias hypotheses excogitet et imagines hic aptas, ille aptiores, eandem tamen motus apparentiam causantes, ac esse unicuique liberum, imo gratificaturum si commodiores excogitet, ita a vindicandi severitate ad exquirendj illecebras avocatj ac provocatj, primum erunt aequiores, tum frustra quaerentes pedibus in authoris sententiam ibunt" (tamże, pisownia oryginalna).

${ }^{45}$ Osiander nie używał terminu „ratowanie zjawisk”. 
wyrażające stosunek autora De revolutionibus do powyższych sugestii, a w dodatku nie jest to cytat $\mathrm{z}$ listu Kopernika, lecz jedynie jego interpretacja dokonana przez Keplera. Według niej „Kopernik wzmocniony stoicką stanowczością umysłu stał na stanowisku, iż powinien otwarcie publikować swoje przekonania, nawet kosztem nauki”46. Odrzucił zatem propozycję przedstawienia hipotezy heliocentrycznej jako narzędzia służącego do ratowania zjawisk.

Po 20 września 1541 roku Retyk opuszcza Warmię i udaje się do Wittenbergi ${ }^{47}$. Nie jest pewne, czy zabrał ze sobą rękopis De revolutionibus. Kopernik, według świadectwa Gassendiego, przekazał rękopis Giesemu. Ten zaś dopiero przesłał go Retykowi ${ }^{48}$. Nie mógł on jednak nadzorować druku, ponieważ uniwersytet w Wittenberdze powołał go na dziekana Wydziału Sztuk Wyzwolonych. Funkcję tę objął w październiku 1541 roku i sprawował do kwietnia roku następnego. Natomiast od semestru zimowego 1542 roku wykładał matematykę na uniwersytecie w Lipsku" ${ }^{49}$. W związku z zaistniałą sytuacją kontrolę nad drukiem De revolutionibus przejął Osiander. Około 21 marca 1543 roku ukończono w Norymberdze druk De revolutionibus ${ }^{50}$.

Kopernik poważnie zachorował około 8 grudnia 1542 roku $^{51}$. Podczas choroby opiekę nad nim sprawowali kanonicy warmińscy Jerzy Donner i Fabian Emerich (1477-1559). Astronom chorował całą zimę i wiosnę roku następnego. Miał krwotok, paraliż prawej strony i tracił przytomność. Zmarł we Fromborku 24 maja 1543 roku. Zgodnie z przekazem tradycji w ostatnich dniach jego życia z Norymbergi dotarło do Fromborka jego wydrukowane

46 Kepler, „Apologia pro Tychone”, 97. „Copernicus Quidem Stoica rigiditate obfirmatus, animi sensa candide sibi profitenda putavit, etiam cum dispendio hujus scientiae” (tamże).

47 Por. Sikorski, „Mikołaj Kopernik na Warmii, chronologia życia i działalności” 535, 512.

48 Por. Bartoszewicz, „Przedmowa tłumacza”, III; por. Sikorski, „Mikołaj Kopernik na Warmii, chronologia życia i działalności” 535, 512. „[...] przy czym Kopernik zachował sobie kopię dzieła" (tamże).

49 Por. Włodarczyk, „Wstęp”, 34.

50 Por. Biskup, „Regesta Copernicana”493, 216; por. Sikorski, „Mikołaj Kopernik na Warmii, chronologia życia i działalności” 557, 516.

51 Por. Sikorski, „Mikołaj Kopernik na Warmii, chronologia życia i działalności” 552, 515. 
dzieło. Donner włożył je w jego ręce, ale wątpliwe jest, aby astronom był tego świadom ${ }^{52}$.

\section{Problem z Przedmowa Kopernika}

Usunięcie Przedmowy (Praefatio), a umieszczenie w jej miejsce Ad Lectorem przez Osiandra, jak to zostało wcześniej ukazane w artykule, spotkało się z ogólną dezaprobatą. Do głosów krytyków dołączył Alojzy Tujakowski. Według niego: „Przedstawienie teorii Kopernika jedynie jako hipotezy, możliwej do przyjęcia obok dawnej teorii Ptolemeusza, jako pewnej dogodnej propozycji innego sposobu przeprowadzania obliczeń astronomicznych, było zaprzeczeniem właściwej idei naukowej i światopoglądowej Kopernika, było całkowicie nie do przyjęcia. Ostry protest Kopernika przeciw zmianie tekstu przedmowy w jego dziele świadczy o głębokim przekonaniu autora o słuszności swojej teorii. Chcąc umocnić obronę swego stanowiska, przesłał Kopernik Osjandrowi w 1542 roku dodatkowo dwa listy: do papieża Pawła III, stanowiący właściwą dedykację, i list kardynała Schönberga, w którym namawia on Kopernika do ogłoszenia swojej teorii. Odwołanie się do najwyższych autorytetów Kościoła było właściwie rozumianą obroną, jaką podjął Kopernik przed możliwymi atakami teologów"53. W powyższym, krytycznym tekście dotyczącym Osiandra mamy do czynienia z kilkoma kontrowersjami. Po pierwsze, nie do końca można się zgodzić z twierdzeniem, iż Kopernik nie rozważał przedstawienia swojej teorii jako „pewnej dogodnej propozycji innego sposobu przeprowadzania obliczeń astronomicznych". Możemy suponować, że Kopernik posłuchał rady Osiandra, żeby „napomknąć w przedmowie”, że uważa hipotezę heliocentryczną za użyteczne narzędzie ratujące zjawisko. Otóż w Liście dedykacyjnym pisze on o tym expressis verbis: skoro „[...] innym przede mną przyznawano swobodę wymyślania dowolnych kół dla objaśnienia zjawisk gwiezdnych - doszedłem i ja do wniosku, że i ja bez przeszkód mam prawo próbować, czy przez przy-

52 Por. Birkenmajer. „Przedmowa”, 23; por. Sikorski, „Mikołaj Kopernik na Warmii, chronologia życia i działalności” 567, 518.

53 Tujakowski, Mikołaja Kopernika „De revolutionibus”, 24-26. 
jęcie jakiegoś ruchu Ziemi nie dałoby się wynaleźć pewniejszych niż tamte sposoby na objaśnienie obrotów sfer niebieskich" ${ }^{54}$.

Po drugie, pojawia się wątpliwość związana z „ostrym protestem Kopernika przeciw zmianie tekstu przedmowy". Wyrazem tego protestu miały być dwa listy przekazane przez Kopernika Osiandrowi w $\left(\mathrm{czerwcu}^{55}\right) 1542$ roku: jeden „do papieża Pawła III, stanowiący właściwą dedykację, i list kardynała Schönberga". Listy te miały stanowić przedmowę do De revolutionibus. Należy zauważyć, że do 29 maja 1542 roku zostały wydrukowane tylko dwa arkusze De revolutionibus ${ }^{56}$, a nie całe dzieło (sto arkuszy) ${ }^{57}$. W związku z tym faktem z całą pewnością przed wysłaniem tych dwóch listów nie dotarła żadna informacja z Norymbergi do Fromborka o umieszczonej nieautoryzowanej przedmowie Ad Lectorem na początku dzieła.

Po trzecie: występuje problem ze „zmianą tekstu przedmowy”, tzn. z jej usunięciem. Pojawia się pytanie: czy usunięty tekst Kopernika stanowił Przedmowę do całości dzieła, czy tylko do księgi pierwszej? Odpowiedź na nie zależy od konkretnego wydania dzieła, które weźmiemy pod uwagę.

W Przedmowie tłumacza do warszawskiego wydania $O$ obrotach ciał niebieskich z 1854 roku Julian Bartoszewicz stwierdził: „[...] Osiander usunął przedmowę Kopernika, w której astronom polski stanowczo rozprawia o ruchu planet około Słońca jako o żadnej wątpliwości nieulegającym fakcie, i tenże Osiander napisał swoją, w której pomysły Kopernika podaje za hipotezę najdokładniej tłumaczącą nieodgadnione dotąd zjawiska wszechświata" ${ }^{58}$.

W wydaniu z roku 1976 Aleksander Birkenmajer zaznacza, że „Przedmowa do I księgi, przekazana nam przez autograf Kopernika, została opuszczona w wydaniu z 1543 roku, które tę księgę rozpoczyna dopiero od pierwszego rozdziału, tak samo ma się sprawa w wydaniu bazylejskim z 1566 roku

${ }^{54}$ Mikołaj Kopernik, O obrotach, przeł. Mieczysław Brożek (ks. I), Stefan Oświecimski (ks. II-VI), w: Dzieła wszystkie, t. II (Warszawa-Kraków: PWN, 1976), 5. Trudno zgodzić się z opinią Tujakowskiego, że „Nigdzie [...] Kopernik nie wyraża wątpliwości, że swoje odkrycia traktuje jako możliwe lub niemożliwe do przyjęcia hipotezy" (Tujakowski, Mikołaja Kopernika „De revolutionibus”, 28).

55 Por. Biskup, „Regesta Copernicana” 542, 513.

56 Por. Sikorski, „Mikołaj Kopernik na Warmii, chronologia życia i działalności” 541, 513.

57 Por. tamże 546, 514.

58 Bartoszewicz, „Przedmowa tłumacza”, LXXIII-LXXIV. 
i w wydaniu amsterdamskim z 1617 roku. Ta więc przedmowa pozostała nieznana szerszemu ogółowi aż do połowy XIX wieku., kiedy po raz pierwszy ogłosiło ją drukiem wydanie warszawskie z 1854 roku"59.

Pomiędzy tymi dwoma wydaniami De revolutionibus zachodzi zasadnicza różnica. Przedmowa w wydaniu warszawskim z 1854 roku jest wstępem do całości dzieła, natomiast w edycji jubileuszowej z 1976 roku stanowi wstęp do księgi pierwszej.

W wydaniu warszawskim została ona umieszczona jako czwarty tekst poprzedzający zasadniczą treść dzieła. Układ tego wydania jest następujący: na początku znajduje się przedmowa Osiandra: Do czytelnika o zasadach tego dzieła (Ad Lectorem de hypothesibus hujus operis); po niej jest umieszczony list Mikołaja Schönberga: Mikołaj Schönberg Kardynał Kapuański Mikołajowi Kopernikowi Pozdrowienie (Nicolaus Schonbergius Cardinalis Capuanus Nicolao Coperniico Salutem); trzecim tekstem jest List dedykacyjny Kopernika: Do Jego Świątobliwości Pawła III Papieża. Mikołaja Kopernika Przedmowa do dzieła: O obrotach ciał niebieskich (Sanctissimum Dominum Paulum III Pontificem Maximum, Nicolai Copernici Praefatio in Libros revolutionum); a na samym końcu przed właściwym tekstem De revolutionibus znajduje się Przedmowa (Praefatio) Kopernika. Biorąc pod uwagę układ De revolutionibus z wydania warszawskiego, należy zgodzić się z twierdzeniem, że Osiander usunął Przedmowę (Praefatio) Kopernika, a na początku dzieła umieścił własny tekst: Ad Lectorem de hypothesibus hujus operis.

W wydaniu jubileuszowym z 1976 roku Przedmowa (Praefatio) Kopernika została umieszczona na początku księgi pierwszej. Biskup, biorąc pod uwagę wydanie norymberskie De revolutionibus, stwierdza, że właściwą przedmową do dzieła Kopernika jest List dedykacyjny, a nie Ad Lectorem. Przedmowe (Praefatio) Kopernika, pominiętą przez Osiandra, umieszcza na początku księgi pierwszej. Takie jej usytuowanie jest zgodne z jej treścią, głosi ona bowiem „[...] pochwałę nauk astronomicznych jako wyjaśniających cały układ świata; [Biskup dodaje, iż] przedmowa ta znajduje się w rękopisie dzieła"60.

59 Aleksander Birkenmajer, „Komentarz”, w: Mikołaj Kopernik. O obrotach, przeł. Mieczysław Brożek (ks. I), Stefan Oświecimski (ks. II-VI) (Warszawa-Kraków: Państwowe Wydawnictwo Naukowe, 1976), 331.

${ }^{60}$ Biskup, „Regesta Copernicana” 493, 216. W czerwcu 1543 roku „Mikołaj Kopernik wysyła do Norymbergi napisaną przez siebie Przedmowę do ksiąg O obrotach (Ad Sanctissimum 
Jeżeli przyjąć za wydaniem jubileuszowym, zgodnym z rękopisem dzieła, że przedmową do De revolutionibus jest List dedykacyjny, to de facto Osiander nie usunął przedmowy Kopernika do jego dzieła, lecz poprzedził ją własną, niepodpisaną. Oczywiście należy zaznaczyć, że "tylko" usunął Przedmowę (Praefatio) do księgi pierwszej. Pojawia się pytanie: dlaczego to zrobił?

\section{Zmiany dokonane przez Osiandra}

Osiander w pracy redakcyjnej związanej z wydaniem De revolutionibus dokonał trzech zasadniczych zmian: dodał niepodpisaną przez siebie Przedmowę, zmienił sam tytuł dzieła oraz usunął Przedmowę Kopernika do księgi pierwszej. W Ad Lectorem zwraca uwagę czytelnika, iż praktyka hipotezy jest akceptowalną, a nie naganną techniką stosowaną w astronomii. Zadaniem astronomii jest rekonstrukcja „[...] ruchów niebieskich na podstawie nieustannej i ścisłej obserwacji”. Znając skutek, czyli ruchy ciał niebieskich, można na ich podstawie „[...] wymyślić jakiekolwiek ich przyczyny albo hipotezy, [...] i tak powiązać je w całość, żeby na ich podstawie te same ruchy można było trafnie obliczyć, według zasad geometrii, zarówno dla przyszłości, jak i dla przeszłości” ${ }^{61}$.

Osiander, aby uzasadnić prezentowane przez siebie stanowisko, odwołuje się w Ad Lectorem do zasad logiki scholastycznej. Prawdziwa przyczyna warunkuje prawdziwy skutek. Gdy zaś mamy do czynienia z sytuacją odwrotną, tzn. mamy dopasować przyczynę do znanego nam skutku, to nawet $\mathrm{z}$ fałszywej przyczyny możemy wywnioskować prawdziwy skutek. Stąd jego wniosek dotyczący odkrycia rzeczywistej przyczyny (w drugim przypadku) jest sceptyczny: „prawdziwych przyczyn w żaden sposób osiągnąć się nie da”62.

Dominum Paulum III Pontificem Maximum, Nicolai Copernici Praefatio in libros Revolutionum)” (Sikorski, „Mikołaj Kopernik na Warmii, chronologia życia i działalności” 542, 513-514).

${ }^{61}$ Andrzej Osiander, List dedykacyjny, tłum. Aleksander Birkenmajer, w: Mikołaj Kopernik, O obrotach, 327.

62 Tamże, 327. „Logicy scholastyczni dobrze znali zasadę, że zjawiska nie mogą jednoznacznie zdeterminować hipotez, mających je »zachować«, czyli wyjaśnić, ponieważ te same 
Hipotezy astronomiczne „Nie potrzebują [...] być prawdziwe ani nawet zbliżone do prawdy, lecz wystarczy to jedno, że dają obliczenia zgadzające się z obserwacjami”" ${ }^{63}$. Osiander nie twierdzi, że hipotezy przyjęte przez Kopernika są fałszywe, lecz że nie ma takiego kryterium, które umożliwiłoby odróżnienie prawdziwych założeń od fałszywych. Według niego astronomia „[... ] nie zna dogłębnie i jasno przyczyn obserwowanych ruchów nieregularnych”64. A ponieważ „[...] do jednego i tego samego ruchu różne się nieraz nastręczają hipotezy, jak np. przy ruchu Słońca mimośrodowość i epicykli, astronom tej się przede wszystkim chwyta, która do zrozumienia jest najłatwiejsza" ${ }^{65}$.

W końcowej części Ad Lectorem Osiander przyjmuje hierarchię nauk według pewności wiedzy: „Filozof będzie może szukał raczej prawdopodobieństwa, lecz ani jeden [astronom], ani drugi [filozof przyrody] nie jest w stanie uchwycić czy podać niczego pewnego, chyba że mu to objawi boskie natchnienie"66. Astronomię umieszcza na najniższym stopniu w hierarchii wiedzy. Polega ona na zmysłowych obserwacjach, dlatego nie potrafi stwierdzić niczego pewnego o prawdziwych przyczynach zjawisk. Na drugim miejscu sytuuje filozofię naturalną. Należy zaznaczyć, że w filozofii XVI i XVII wieku dochodzi do głosu sceptycyzm epistemologiczny ${ }^{67}$. Dlatego filozofia naturalna nie może ustalić wiedzy pewnej o przyczynach danego zjawiska, lecz tylko prawdopodobną. Na trzecim, najwyższym stopniu plasuje teologię. Absolutną pewność wiedzy czerpie ona z Objawienia Bożego, zgodnie z zasadą reformacji, że tylko Pismo Święte (sola scriptura) jest gwarantem poznania. Stąd człowiek może cokolwiek poznać pewnego, o ile „mu to objawi boskie natchnienie”. Możemy powiedzieć, że przekonania religijne Osiandra zawa-

wnioski mogą być wyprowadzone z bardzo odmiennych przesłanek, a eksperymentalna weryfikacja następnika nie upoważnia nas do uznania poprzednika. Zasada ta, rozwijana w Oxfordzie w XIII i XIV wieku, była powszechnie znana w szkole logiki w Padwie na początku XVI wieku" (Alistair C. Crombie, Nauka średniowieczna i początki nauki nowożytnej, t. 2, przeł. Stanisław Łypacewicz (Warszawa: Pax, 1960), 38-39).

${ }^{63}$ Birkenmajer, Dobrzycki, „Komentarz”, 327.

${ }^{64}$ Tamże.

65 Tamże.

66 Tamże.

${ }^{67}$ Por. Izydora Dąmbska, Sceptycyzm francuski XVI i XVII wieku (Toruń: Towarzystwo Naukowe w Toruniu, 1958). 
żyły na jego opinii dotyczącej astronomii i hipotez z nią związanych. Według niego dowolna liczba konkurujących ze sobą hipotez może tłumaczyć obserwowany ruch planet. Nie ma natomiast żadnego kryterium, poza Objawieniem Bożym, według którego można by ocenić, która hipoteza odpowiada rzeczywistemu stanowi rzeczy. Na zakończenie Przedmowy jeszcze raz podkreśla, że zadaniem astronomii jest tłumaczenie zjawisk, a nie ukazywanie prawdy o nich: „[...] niech nikt co do założeń w astronomii nie oczekuje od niej niczego pewnego, skoro ona sama nic takiego dać nie może, by człowiek, biorąc za prawdę rzeczy wymyślone do innego użytku, nie wyszedł z tej nauki głupszy, niż do niej przystąpił"68.

Osiander, oprócz dodania Przedmowy (Ad Lectorem) do dzieła, zmienił także jego tytuł, dodając wyrazy: orbium coelestium. Libri VI. W wyniku tego zabiegu tytuł pierwszego, norymberskiego wydania opus vitae Kopernika brzmiał: De revolutionibus orbium coelestium. Libri VI. Jaki cel mu przyświecał, że dokonał jego zmiany? Pierwotny tytuł - De revolutionibus (O obrotach) - niejako zmuszał czytelnika do szukania odpowiedzi na pytanie: o jakich obrotach jest mowa w książce? Dodanie zaś do De revolutionibus wyrazów orbium coelestium. Libri VI stawiało sprawę jasno - opublikowane dzieło dotyczy klasycznych problemów astronomii. Czy poszerzenie tytułu było celowym wprowadzeniem czytelnika w błąd? ${ }^{69}$ Sprawa jest dyskusyjna.

Trzecią zmianą, jakiej dokonał w dziele, było usunięcie Wstępu do księgi pierwszej. Kopernik wygłasza w nim pochwałę tych nauk, którym „[...] przede wszystkim poświęcić się należy i te z największym uprawiać zapałem, które obracają się w kręgu rzeczy najpiękniejszych i najbardziej godnych poznania"70. Królową nauk, zgodnie z przyjętą hierarchią, była wówczas teologia. Jednak Kopernik nie ją gloryfikuje, lecz astronomię. Według niego to astronomia jest „głową sztuk wyzwolonych", ponieważ rozważa sprawy, które są

68 Birkenmajer, Dobrzycki, „Komentarz”, 327.

69 Tujakowski, Mikołaja Kopernika „De revolutionibus”, 17. Tytuł ten pozostał bez zmian w trzech następnych wydaniach: bazylejskim (1566), amsterdamskim (1617) i warszawskim (1854): O obrotach ciał niebieskich. Ksiagg sześć. Tujakowski wskazuje na jeszcze dwie dodatkowe zmiany wprowadzone przez Osiandra: na karcie tytułowej dodał tekst reklamujący książkę i greckie motto „Niech nie wchodzi nieznający geometrii”. Por. Tujakowski, Mikołaja Kopernika „De revolutionibus”, 39.

70 Kopernik, O obrotach, 7. 
„[...] ustanowione [...] w najlepszym ładzie i boską kierowane wolą. W związku z tym pyta retorycznie: czy człowiek, widząc harmonię świata, „[...] nie wzniesie się na wyżyny cnoty przez pilne ich rozważanie i stałą jakby zażyłość z nimi i nie będzie podziwiał Stwórcy wszechrzeczy, w którym się mieści całe szczęście i wszelkie dobro?".

Dokonana przez Kopernika gloryfikacja astronomii nie zgadzała się z jej koncepcją zaprezentowaną w Ad Lectorem. Zgodnie z nią jest ona narzędziem przydatnym do tłumaczenia ruchu planet, bez pretensji do prawdziwości; a poza tym to nie ona, jak to przedstawił astronom z Fromborka, ale teologia jest królową nauk. Powyższy zachwyt Kopernika dotyczący astronomii, czyli odkrycia zamysłu Stwórcy wobec wszechświata, należało pominąć. Dotyczy to także końcowych zdań Wstępu. Kopernik po raz drugi podważa w nich „królewską godność" teologii wobec innych nauk, kiedy pisze o trudnościach, jakie stoją przed astronomią: „[...] ta boska raczej niż ludzka nauka, zagłębiająca się w rzeczy najwznioślejsze, nie jest pozbawiona trudności"71. Podstawową trudnością, na którą zwraca uwagę autor De revolutionibus, są rozbieżne założenia przyjmowane przez filozofów w astronomii w celu wyjaśnienia ruchu planet: „[...] nie zgadzali się między sobą co do jej podstawowych założeń, zwanych po grecku hipotezami”. Taka rozbieżność nie stanowiła żadnej przeszkody w jej rozumieniu dla ówczesnych myślicieli. Astronomia nie miała ukazywać rzeczywistej struktury świata. Jej założenia mogły być fałszywe, dlatego nie może być ona „wiedzą doskonałą”, za jaką ją uważał Kopernik ${ }^{72}$.

Pozostaje nam podjąć próbę odpowiedzi na pytanie: dlaczego Osiander zostawił bez podpisu Ad Lectorem?

\section{Anonimowość Ad Lectorem}

Odpowiedź na pytanie, dlaczego Osiander nie podpisał dodanej przez siebie przedmowy Do czytelnika, jest złożona. Możemy zgodzić się z Owenem Gingrichem, że jej anonimowość nie wynikała z jakiejkolwiek złośliwości

\footnotetext{
71 Tamże, 7.

72 Por. tamże, 8.
} 
z jego strony, ale raczej z luterańskiej niechęci do bycia związanym z książką poświęconą papieżowi ${ }^{73}$. Na brak poświadczenia jej autorstwa złożyło się wiele przyczyn.

Po pierwsze, należy wziąć pod uwagę ówczesny kontekst historyczno-polityczny. Umieszczenie nazwiska znanego luterańskiego reformatora w dziele napisanym przez kanonika i uczonego katolickiego niemal gwarantowałoby jego dokładniejszą analizę przez Kościół i zwiększyłoby niekorzystną reakcję teologów. Kopernik chciał tego uniknąć c $^{74}$. Wzbudziłoby to także podejrzenie Inkwizycji wobec samego autora. Zaledwie rok wcześniej, tj. w 1542 roku, Inkwizycja została zreformowana przez papieża Pawła III. Powołano Święte Oficjum (Sacrum Officium), które między innymi miało zlikwidować wpływy luterańskie w Kościele. Druk De revolutionibus nastąpił w bardzo napiętym okresie polityczno-religijnym, kiedy sytuacja protestantów i niepodległość Norymbergi były zagrożone przez stronnictwo katolickie ${ }^{75}$. Istniały uzasadnione powody, aby sądzić, że wojska Świętego Rzymskiego Cesarstwa wkrótce przywrócą nad nim kontrolę. Wtedy księgi protestanckich teologów mogłyby zostać spalone. Taką praktykę stosowano po obu stronach konfliktu religijnego. Anonimowość Ad Lectorem była jedynym możliwym sposobem ochrony dzieła w tak niepewnej sytuacji. Za taką interpretacją przemawia... potraktowanie Retyka przez Kopernika. Przyczynił się on do spopularyzowania doktryny heliocentrycznej (Relacja pierwsza) oraz do druku De revolutionibus. Mimo to Kopernik w Liście dedykacyjnym dla papieża nie wspomina swojego luterańskiego ucznia jako jednego z tych, których pomoc i zachęta przekonały go do opublikowania dzieła ${ }^{76}$.

${ }^{73}$ Por. Gingerich, „From Copernicus to Kepler: Heliocentrism as Model and as Reality", 514.

74 Por. Kopernik, O obrotach, 5.

75 Por. Wrightsman, „Andreas Osiander's Contribution to the Copernican Achievement", 220.

76 Biskup chełmiński Tiedemann Giese w liście do Retyka z 26 lipca 1543 roku prosi go, aby „[...] dołączył swoje dziełko, w którym trafnie bronił ruchu Ziemi przed niezgodnością z Pismem Świętym, co wynagrodzi mu przykrość spowodowaną przemilczeniem jego osoby w przedmowie przez Kopernika. Spowodowane to było nie lekceważeniem, ale ociężałością i pewną niedbałością Kopernika, a przy tym tracił on już siły, zresztą mniej zwracał uwagę na to, co nie było związane z filozofią” (Biskup, „Regesta Copernicana” 503, 220); por. Sikorski, „Mikołaj Kopernik na Warmii, chronologia życia i działalności” 567, 518-519. 
Po drugie, w tekście Ad Lectorem Osiander odnosi się do „autora” dzieła, nie pozostawiając wątpliwości uważnemu czytelnikowi, że autorem przedmowy nie jest Kopernik ${ }^{77}$. Ponadto jej edycja różni się od edycji Listu dedykacyjnego. Ten ostatni jest wyraźnie oznaczony u góry każdej strony napisem Praefatio Autoris, tzn. że przedstawiony tekst pochodzi od autora. Takiego napisu nie ma ani w przypadku tekstu Ad Lectorem, ani w liście Mikołaja Schonberga zachęcającego Kopernika do opublikowania De revolutionibus (Nicolaus Schonbergius cardinalis Capuanus, Nicolao Copernico). Wynika $\mathrm{z}$ tego, że Osiander nie próbował przypisać autorstwa Ad Lectorem Kopernikowi.

Po trzecie, należy zaznaczyć, że nie zaprzeczał on, iż jest autorem Przedmowy. „Otwarcie przyznał” Philipowi Apianowi (1531-1589), profesorowi astronomii w Tübingen, że on ją napisa17 ${ }^{78}$.

Po czwarte, w wieku dominującego sceptycyzmu jedyne źródło wiedzy pewnej stanowiło objawienie Boże. Był on wierny tej zasadzie, dlatego według niego hipotezy astronomiczne nie mogły rościć sobie prawa do prawdziwego przedstawienia świata; służyły jedynie jako podstawa obliczeń.

Po piąte, twierdzenie Osiandra, że astronomia ma w sobie nieodłączny element hipotetyczny, powszechnie aprobowano w XVI wieku. Jego poglądy były zgodne z metodologicznymi standardami owego czasu i kryteriami ocen akceptowalnych wyjaśnień astronomicznych. Większość astronomów matematycznych, tak jak on, zajęła stanowisko „instrumentalistyczne” w odniesieniu do teorii astronomicznych. Dzięki temu zabiegowi publikacja De Revolutionibus nie wywołała żadnej reakcji kościelnej ani ze strony katolickiej ${ }^{79}$, ani protestanckiej.

Pomimo powyższych argumentów usprawiedliwiających niejako czyn Osiandra należy zauważyć, że oprócz dodania przez niego przedmowy Ad Lectorem zmienił on także sam tytuł dzieła i usunął z niego Przedmowę do

77 „[...] autor tego dzieła nie dopuścił się niczego takiego, co by zasługiwało na potępienie” (Birkenmajer, Dobrzycki, „Komentarz”, 327); „A właśnie ten mistrz w wyborny sposób dał tutaj jedno i drugie. [...]. I jeżeli jakieś przyczyny wynajduje z pomocą wyobraźni, a wynajduje ich rzeczywiście jak najwięcej, to nie na to przecież wymyśla je...” (tamże).

78 Por. Rosen, Three Copernican Treatises, 404.

79 Święte Oficjum zainteresowało się De revolutionibus dopiero w 1620 roku. 
księgi pierwszej. Te trzy fakty świadczą o tym, że chciał on podporządkować treść De revolutionibus instrumentalnej koncepcji astronomii.

\section{Ratowanie zjawisk i instrumentalizm Osiandra}

Jednym z głównych stanowisk metodologicznych astronomii był słynny nakaz „ratowania zjawiska” ( $\sigma \dot{\omega} \xi \varepsilon \varepsilon v \tau \alpha \dot{\alpha} \phi \alpha \iota v o ́ \mu \varepsilon v \alpha$, salvare apparentias). Pojawił się on w starożytnej Grecji jako status poznawczy teorii astronomicznych ${ }^{80}$. W filozofii platońskiej nakaz ten oznaczał ujawnienie prawdziwej natury tego, co jest postrzegane zmysłami. Platon, nakładając wymóg, by ruchy ciał niebieskich były kołowe, gładkie i uporządkowane, postawił przed matematykami zadanie, aby ich hipotezy ocaliły zjawiska, które jawią się zmysłom jako nieuporządkowane. Od Arystotelesa nakaz ten zmienił swoje znaczenie i stał się mottem astronomii, która wyrzekła się wiedzy o rzeczywistości i zadowoliła się opisem samych zjawisk. Według Duhema ${ }^{81}$ związek istniejący między kosmologią (filozofią naturalną) a astronomią niejako ilustruje podrzędny status matematyki (astronomii) wobec filozofii naturalnej. Od starożytności do czasu Kopernika traktowano je jako niezależne dyscypliny naukowe, posługujące się odrębnymi metodami. Zadaniem astronomii było przewidywanie pozycji i ruchu planet przy użyciu odpowiednich urządzeń i obliczeń matematycznych. Satysfakcjonująca teoria astronomiczna powinna „ocalić zjawiska”, natomiast nie musi być prawdziwa. Ukazanie prawdy o świecie należało do filozofii naturalnej ${ }^{82}$.

W czasach współczesnych Kopernikowi i Osiandrowi hipoteza ratowania zjawisk stała się ogólnie przyjętą i stosowaną dyrektywą badawczą. Rainer Gemma z Fryzji (1508-1555), który w liście do Jana Dantyszka z 20 lipca 1541 roku stwierdził: „Ja bowiem nie dysputuję teraz o hipotezach, których (ów autor) używa do swego dowodu [...]. Nie zależy mi na tym, czy [Kopernik]

80 Por. Duhem, Sôzein ta phainomena, 3-4.

${ }^{81}$ Por. Pierre Duhem, La théorie physique. Son objet, sa structure (Lyon: ENS Éditions, 2016).

${ }^{82}$ Por. Arystoteles, Analityki pierwsze, przeł. Kazimierz Leśniak, w: Dzieła wszystkie, t. I (Warszawa: Państwowe Wydawnictwo Naukowe, 1990), 151. 
twierdzi, że Ziemia obraca się, czy też trwa nieruchoma, byle byśmy ruchy gwiazd i odstępy czasów rozpoznali ściśle i ujęli je w najdokładniejszy rachunek" ${ }^{83}$, jest zainteresowany zastosowaniem heliocentrycznej hipotezy do obliczeń ruchu gwiazd. Pomija zaś pytanie o jej prawdziwość. Podobnie postąpił Erasmus Reinhold (1511-1553), który z powodzeniem zastosował ją w Tablicach Prutenicznych (1551) (Tabulae Prutenicae), nie zastanawiając się nad jej prawdziwością ${ }^{84}$. Kardynał Robert Bellarmin (1542-1621) użył jej podczas kontrowersji kopernikańskiej przeciwko Galileuszowi (1564-1642). W Liście do o. Paolo Foscariniego z 12 kwietnia 1615 roku ${ }^{85}$ przestrzegał zarówno karmelitę (Foscariniego ok. 1565-1616), jak i Galileusza przed jej popieraniem i rozpowszechnianiem jako prawdziwego opisu świata. Według niego teorię Kopernika należy pojmować jako hipotezę ex suppositione. „Nie jest bowiem tą samą rzeczą udowodnić, że udaje się wyjaśnić pewne zjawiska, jeśli założy się, iż Słońce znajduje się w centrum świata, zaś Ziemia na niebie, oraz udowodnić, że w istocie rzeczy [in verita] Słońce znajduje się w centrum świata, zaś Ziemia na niebie. Dowód pierwszej z hipotez, jak sądzę, może istnieć, lecz jeśli chodzi o dowód drugiej, to mam poważne wątpliwości, zaś w przypadku wątpliwości nie należy porzucać Pisma Świętego wyłożonego przez świętych Ojców"86.

Osiander i Bellarmin byli przekonani, że tylko te teorie, których ważność została ustalona w sposób konieczny, mogą być uznane za prawdziwy opis rzeczywistości. W przypadku hipotezy heliocentrycznej nie jesteśmy w stanie dowieść jej prawdziwości w ten sposób. Dlatego według Pierre’a Duhema logika była po stronie Osiandra i Bellarmina ${ }^{87}$, a nie po stronie Kopernika, Keplera i Galileusza.

83 Sikorski, „Mikołaj Kopernik na Warmii, chronologia życia i działalności” 529, 511.

84 Większość ówczesnych filozofów i teologów postępowała podobnie, była przeciwna uznaniu Kopernikańskiej hipotezy ruchu Ziemi za rzeczywistą. Dokładniejsze omówienie tego problemu patrz: Edward Rosen, "Galileo's Misstatements about Copernicus”, Isis 49, 3 (1958): 319-330.

${ }^{85}$ Por. Robert Bellarmin, „List do o. Paolo Antonio Foscariniego z 12 kwietnia 1615 roku”, przeł. Tadeusz Sierotowicz, w: Galileo Galilei, Listy kopernikańskie (Tarnów: Biblos, 2006), 93.

${ }^{86}$ Por. tamże, 94.

87 Por. Duhem, Sôzein ta phainomena, 136. 


\section{Zakończenie}

Na podstawie dostępnych dokumentów, a w szczególności listów i treści samej przedmowy Ad Lectorem, możemy stwierdzić, że została ona umieszczona bez wiedzy i zgody Kopernika w jego dziele. Pozostawienie jej bez podpisu było chęcią zmylenia czytelnika, który miał myśleć, że jej twórcą jest sam autor. Za takim odczytaniem intencji Osiandra przemawiają fakty: dodał Ad Lectorem, zmienił tytuł dzieła i usunął $\mathrm{z}$ niego Przedmowe do księgi pierwszej. Ingerencja w treść dzieła miała na celu zmianę jego rozumienia. Czytelnik powinien czytać De revolutionibus nie jako realistyczny opis świata, ale jako hipotezę ratującą zjawiska.

Nie ma dowodów na poparcie poglądu, że przedmowa Ad Lectorem negatywnie wpłynęła na odbiór De revolutionibus i spowodowała jego potępienie czy też osłabiła jego oddziaływanie lub zaszkodziła jego reputacji w jakikolwiek sposób. O wiele bardziej prawdopodobne jest twierdzenie, że przez blisko sto lat uchroniła je przed kontrolą Inkwizycji podczas okresu konfliktu ideologicznego i politycznego.

Wpływ na postrzeganie przez Osiandra teorii heliocentrycznej jako narzędzia ratującego zjawiska miały czynniki religijne, społeczne i naukowe. Zaprezentowane przez niego stanowisko było zgodne z ówczesną tradycją astronomiczną. Przedmowa stanowiła odzwierciedlenie powszechnego sceptycyzmu dotyczącego teorii naukowych, a także wyraz jego własnych teologicznych przekonań, zgodnie z którymi prawda jest dostępna tylko dzięki Objawieniu Bożemu.

Zatarł on różnicę pomiędzy astronomią matematyczną a fizyką (filozofią naturalną). Odrzucił możliwość poznania istoty rzeczy zarówno przez astronomię, jak i przez fizykę. Konsekwencją przyjętych przez niego założeń było nowe rozumienie nauki. Głosił on de facto fenomenalizm, zgodnie z którym wiedza naukowa została ograniczona „[...] »do tego, co widać«, natomiast wszelkie jej twierdzenia na temat czy to »istot rzeczy«, czy »wewnętrznej struktury rzeczy« należy uznać co najwyżej za użyteczne fikcje"s8.

\footnotetext{
${ }^{88}$ Michał Heller, Filozofia i wszechświat. Wybór pism (Kraków: Universitas, 2006), 387.
} 
Według Karla Raimunda Poppera (1902-1994) instrumentalne ${ }^{89}$ rozumienie hipotez naukowych przez Osiandra i kardynała Bellarmina zostało przyjęte jako „dogmat” w XX wieku. Stało się „oficjalnym poglądem” teorii fizycznych, akceptowanym przez większość wiodących teoretyków fizyki $\mathrm{XX}$ wieku ${ }^{90}$. Nie przyjęli go ani Albert Einstein, ani Erwin Schrödinger, ani on $\mathrm{sam}^{91}$.

\section{Bibliografia}

Arystoteles. 1990. Analityki pierwsze, przeł. Kazimierz Leśniak. W: Dzieła wszystkie. T. I, 89-251. Warszawa: Państwowe Wydawnictwo Naukowe.

Bartoszewicz Julian. 1854. „Przedmowa tłumacza”. W: Mikołaja Kopernika Toruńczyka, O obrotach ciał niebieskich. Ksiąg sześć, przeł. Jan Baranowski, I-LXXV. Warszawa: Drukarnia Stanisława Strąbskiego.

Bellarmin Robert. 2006. „List do o. Paolo Antonio Foscariniego z 12 kwietnia 1615 roku”, przeł. Tadeusz Sierotowicz. W: Galileo Galilei. Listy kopernikańskie. Tarnów: Biblos.

Biskup Marian. 1973. Regesta Copernicana. Studia Copernicana. T. VII. Wrocław-Warszawa-Kraków-Gdańsk: Ossolineum.

Birkenmajer Aleksander, Dobrzycki Jerzy. 1976. „Komentarz”. W: Mikołaj Kopernik. O obrotach, przeł. Mieczysław Brożek (ks. I), Stefan Oświecimski (ks. II-VI), 326-402. Warszawa-Kraków: Państwowe Wydawnictwo Naukowe.

Birkenmajer Ludwik A. 1900. Mikołaj Kopernik. Część pierwsza. Studya nad pracami Kopernika oraz materyały biograficzne. Kraków: Akademya Umiejętności.

Birkenmajer Ludwik A. 1920. Przedmowa. W: Mikołaj Kopernik. Wybór pism w przekładzie polskim, przeł. Ludwik A. Birkenmajer. Kraków: Druk w I. Anczyca i Spółki.

89 Por. Karl R. Popper, „Three views concerning human knowledge”, 97-119. Podobnie twierdzą: Owen Gingerich, „From Copernicus to Kepler: Heliocentrism as Model and as Reality”, Proceedings of the American Philosophical Society 117, 6 (1973): 513-522 i Mark Graubard, „Andreas Osiander: Lover of science or appeaser of its enemies”, Science Education 48, 2 (1964), 168-187.

90 Filozofowie instrumentaliści, podobnie jak Osiander, odrzucili możliwość poznania istoty bytu.

91 Por. Popper, „Three views concerning human knowledge”, 103-105. 
Boyer Alain. 1995. „The Osianderian compromise”. W: The Problem of Rationality in Science and its Philosophy: on Poper vs. Polanyi, the Polish Conference 1988-89, red. Józef Misiek, 55-63. Boston Studies in the Philosophy of Science. Vol. 160, Dordrecht: Springer.

Crombie Alistair C. 1960. Nauka średniowieczna i poczatki nauki nowożytnej. T. 2, przeł. Stanisław Łypacewicz. Warszawa: Pax.

Dąmbska Izydora. 1958. Sceptycyzm francuski XVI i XVII wieku. Toruń: Towarzystwo Naukowe w Toruniu.

Drewnowski Jerzy. 1978. Mikołaj Kopernik w świetle swej korespondencji. Wrocław-Warszawa-Kraków-Gdańsk: Ossolineum.

Duhem Pierre. 1908. Sozein ta phainomena. Essai sur la Notion de Théorie physique de Platon à Galilée. Paris: A. Hermann et Fils.

Duhem Pierre. 1913-1959. Le Système du Monde. Histoire des Doctrines cosmologiques de Platon à Copernic. T. 1-10. Paris: A. Hermann et Fils.

Duhem Pierre. 2016. La théorie physique. Son objet, sa structure. Lyon: ENS Éditions.

Gingerich Owen. 1973. „From Copernicus to Kepler: Heliocentrism as Model and as Reality". Proceedings of the American Philosophical Society 117, 6: 513-522.

Graubard Mark. 1964. „Andreas Osiander: Lover of science or appeaser of its enemies". Science Education 48, 2: 168-187.

Grobler Adam. 2006. Metodologia nauk. Kraków: Wydawnictwo Aureus-Wydawnictwo Znak.

Heller Michał. 2006. Filozofia i wszechświat. Wybór pism. Kraków: Universitas.

Ingarden Roman S. 1994. Fizyka i fizycy. Studia i szkice z historii i filozofii fizyki. Toruń: Wydawnictwo Uniwersytetu Mikołaja Kopernika.

Kopernik Mikołaj. 1976. O obrotach, przeł. Mieczysław Brożek (ks. I), Stefan Oświecimski (ks. II-VI). W: Dzieła wszystkie. T. II. Warszawa-Kraków: PWN.

Kopernik Mikołaj. 1972. Rękopis Dzieła Mikołaja Kopernika. O obrotach. Facsimile. W: Dzieła wszystkie. T. 1, red. Paweł Czartoryski, Jan Dorociński [technika facsimile]. Warszawa-Kraków: PWN.

Kepler Johannes. 1988. „Apologia pro Tychone contra Ursum”. W: The Birth of History and Philosophy of Science: Kepler's "A Defence of Tycho against Ursus" with essays on its provenance and significance, red. Nicholas Jardine. Cambridge: Cambridge University Press. Reprint.

Kokowski Michał. 2009. Różne oblicza Mikołaja Kopernika. Spotkania z historia interpretacji. Warszawa-Kraków: Instytut Historii Nauki PAN.

Kuhn Thomas S. 2006. Przewrót kopernikański, przeł. Stefan Amsterdamski. Warszawa: Prószyński i S-ka SA.

List Martha. 1978. „Marginalien zur Handexemplar Keplers von Copernicus: De revolutionibus orbium coelestum (Nümberg, 1543)". Studia Copernicana 16: 443-460. 
Nicolai Copernici Toruniensis. 1854. De Revolutionibus Orbium Coelestium libri sex. Accedit G. Joachimi Rhetici Narratio prima, cum Copernici nonullis scriptis minoribus, nunc primum colectis, eiusque vita. O obrotach Ciał Niebieskich ksiag sześć. Nadto Opowiadanie J. Joachima Retyka, różne pisma mniejsze M. Kopernika zebrane i życiorys jego, przeł. Jan Baranowski. Warszawa: Drukarnia Stanisława Strąbskiego.

Polkowski Ignacy. 1873. Kopernikijana, czyli materiały do pism i życia Mikołaja Kopernika. T. 1. Gniezno: Drukiem J. B. Langiego.

Popper Karl R. 1965. „Three views concerning human knowledge”. W: Karl R. Popper. Conjectures and refutations: The growth of scientific knowledge, 97-119. London: Routledge.

Retyk Jerzy J. 2015. Relacja pierwsza z ksiag „O obrotach” Mikołaja Kopernika, przeł. Ignacy Lewandowski. Warszawa: Wydawnictwo Uniwersytetu Warszawskiego.

Rosen Edward. 1958. „Galileo's Misstatements about Copernicus”. Isis 49, 3: 319-330.

Rosen Edward. 1971. Three Copernican Treatises. The Commentariolus of Copernicus. The Letter against Werner. The Narratio prima of Rheticus. New York: Octagon Books.

Sady Wojciech. 1983. „Przeciwko instrumentalizmowi”. Studia Filozoficzne 10: $145-152$.

Sikorski Jerzy. 1973. „Mikołaj Kopernik na Warmii, chronologia życia i działalności”. W: Kopernik na Warmii. Życie i działalność publiczna. Działalność naukowa. Środowisko. Kalendarium, red. Janusz Jasiński, Bohdan Koziełko-Poklewski, Jerzy Sikorski, 427-520. Olsztyn: Stacja Naukowa Polskiego Towarzystwa Historycznego (Instytut Mazurski), Ośrodek Badań Naukowych im. Wojciecha Kętrzyńskiego.

Tujakowski Alojzy. 1973. Mikołaja Kopernika „De revolutionibus”. Historia wydań. Toruń: PWN.

Wasiutyński Jeremi. 1938. Kopernik, twórca nowego nieba. Warszawa: J. Przeworski. Włodarczyk Jarosław. 2015. „Wstęp”. W: Jerzy J. Retyk. Relacja pierwsza z ksiag „O obrotach" Mikołaja Kopernika, przeł. Ignacy Lewandowski, 7-68. Warszawa: Wydawnictwo Uniwersytetu Warszawskiego.

Wrightsman Bruce. 1975. „Andreas Osiander's Contribution to the Copernican Achievement". W: The Copernican Achievement, red. Robert S. Westman, 213-243. Berkeley-Los Angeles-London: University of California Press. 


\begin{abstract}
The Problematic Nature of Andreas Osiander's Preface Ad Lectorem to Nicolaus Copernicus's De revolutionibus
\end{abstract}

Andreas Osiander's Ad Lectorem foreword to Nicolaus Copernicus' De revolutionibus, from its publication in 1543 to the present day, is the subject of numerous controversies. The article synthetically reconstructs the events that led to its creation and placement without a signature in the work. It also shows the reasons for the tension between it and the content of the work itself. The aim of the article is to show that Osiander's misunderstanding of the scientific hypothesis in Copernicus' view is the source of these tensions. The final part of the article presents the consequence of its understanding in the form of modern instrumentalism.

Keywords: Andreas Osiander, Nicolaus Copernicus, De revolutionibus, scientific hypothesis 